\title{
Mother Tongue as an Asset in Developing 12 Reading Comprehension Skill Among Iranian EFL Learners
}

\author{
Farzaneh Iranmanesh (Corresponding author) \\ Department of English, Maybod Branch, Islamic Azad University \\ Maybod, Yazd, Iran \\ E-mail: farzaneiranmanesh@yahoo.com \\ Mohammad Golshan \\ Department of English, Maybod Branch, Islamic Azad University \\ Maybod, Yazd, Iran \\ E-mail: Mohammadgolashann@gmail.com
}

Received: November 13, 2017 Accepted: December 8, 2017 Published: January 9, 2018

doi:10.5296/ijssr.v6i1.12142ＵRL: http://dx.doi.org/10.5296/ijssr.v6i1.12142

\begin{abstract}
This study attempted to explore the effect of teachers switching to 11 on developing 12 reading comprehension among learners and to justify the assumption that their switching to 11 can be purposeful, following pedagogical goals. To this respect two groups of students majoring at English teaching were selected from intact classes, one as the control group, the other as the experimental receiving 12-only and 12 plus 11 switching instruction respectively for their reading comprehension course with the same teacher under equal condition (highly attempted). The result showed that non/low proficient 12 readers who rely more on translation in the process of comprehending English texts made more advantage of the teacher's implementing strategy and developed more than other participants. That is; apart from various reading strategies utilized by EFl learners, teachers' code switching as a compensation strategy to clarify the complex unknown (assumed for the learners) syntactic/semantic structures plays a prominent role in facilitating the struggling task of comprehension among learners. It also justified the premise that insisting on 12-only instruction in reading comprehension is not facilitating but frustrating and time consuming. However, systematic switching to 11 can be developmental and timesaving through making
\end{abstract}


positive effect on comprehension, motivation and confidence. Hence this study can provide language teachers with pedagogical implications for non-proficient 12 readers particularly at the early years of learning process.

Keywords: reading comprehension, codeswitching, foreign/second language learners

\section{Introduction}

It is quite evident that second / foreign language learning is a time processing issue. Hence research in finding solutions, strategies, and criteria for making this process more effective and intensive meanwhile shorter or in other words faster is a matter of undisputed fact. Reading is one of second / foreign language learning skills often a prelude to a speaking or writing activity (Harmer, 2001) involves comprehension process with regard to readers' preexisting knowledge of the world, of textual features, different reading strategies and models and several other factors each taking time per se.

Trugill argued that the concept of code switching is most commonly used within the sociolinguistic field of studies and it is commonly used by bilingual speakers often to signal two different identities at once (as cited in Berg, 2013). Berg stated that regarding switching languages or codes in the actual teaching of foreign languages, the L1 can and should be used as a resource in foreign language classrooms, albeit to varying degrees. According to Cook (2001) instances in which the L1 should be considered to be used are e.g. explaining grammar, task-organization, disciplining students and test implementation. Furthermore, Cook argued that teachers should resort to the L1 if it is apparent that using the target language would be inefficient and/ or problematic for the learner and when the cost of the TL is too great (as cited in Tornbull \& Arnett, 2002). As a way of facilitating and time saving pedagogy the present study seeks the answer to these research questions:

- How can code switching be utilized as a strategy by L2 teachers?

- What impact does this strategy have on the learners reading proficiency?

- What is the role of proficiency level in the learners making benefit of teachers' code switching?

\section{The Review of the Literature}

Using 11 in second or foreign language classroom has always been contentious in the history of second /foreign language teaching. While it has been criticized by George,1972; Krashen,1981; Lado,1964; Perdue1993 (cited in Junja Wang 2005) as a source of errors and negative transfer, tide up with some teaching methods/approaches such as: direct method, total physical response, and the natural approach in which language teaching is conducted using the 12 only, giving great importance to language input, others have been in favor of using 11 (Atkinson, 1987; Dodson, 1967; Nunan \& lamb, 1996) contending that it serves as an efficient, humanistic and flexible way of foreign language teaching.

From a number of language learning perspectives, others (Anton \& Dicamilla, 1998 ; Brooks \& Donato, 1994 ; and Swain \& Lapkin, 2000) point to research indicating that the 11 is a very useful cognitive learning tool in 12 acquisition suggesting that input is quite essential but not 
enough for 12 acquisition (as cited in Liu, 2004). Cook (2001) supported the idea that switching to 11 is a natural phenomenon among those who share two or more languages, hence it deserves a place in TL classroom. He argued that using 11 can be facilitating especially when teaching in the TL is too difficult or time-consuming for the learner to process and understand. Skinner (in Liu, 2004) also opposed L2 only practice in language teaching. He argues that using 12 only as the language of instruction inhibits that process because it obstructs the rapid connection of words with thought, and thereby it slows acquisition of meaning in 12 .

Berg (2013) conducted a study on code switching in ESL teaching. He investigated the reasons the teacher alternate between the target language and the first language in compulsory school while the teachers in upper secondary school exclusively use the target language. His findings showed that as a teacher of second and/ or foreign languages, the matter of being consequent in one's language use, and the realization that using a combination of both the target language and L1 might be a better solution than having some students not being able to comprehend the content of the lesson. Fatemi et al. (2014) studied the effect of code-switching strategies on listening comprehension of EFL students came to the conclusion that using code-switching strategy enhanced students' listening comprehension ability. Participants could cope with more complicated grammatical structures as well as difficult words to process for their meanings.

Teik and Lian (2013) investigated the nature of code-switching in lesson instructions from English as the medium of instructions to Malay, its possible motivations and potential implications on the students. The findings of their study pointed to the strategic use of code-switching from English to Malay as a tool to enhance sacred literacy processes and instructions by capitalizing on the common mother tongue shared by the students and the teacher as it served both facilitating and affective functions. Abdel Magid and Mugaddam came to the conclusion that code-switching has been widely, purposefully and functionally employed as a component of ESL discourses in the classroom (as cited in Fatemi, 2014).

Turnbull and Sweetnam Evans (2017) conducted a study on fifteen Japanese university students of intermediate-level English, investigating the effect of post reading L1 discussions on L2 reading comprehensions. A positive correlation was observed between L1 group discussions and a greater understanding of the L2 texts. They argued that the participants who discussed the texts in their L1 not only recalled the most textual elements and features across all four texts but also produced recalls with the most words, discussed the broadest range of topics, recalled more detailed micropropositions, and had the greatest genre awareness. They reported that the participants who discussed the texts in their L1 were able to negotiate the cognitively-complex processes required for comprehension of the texts and were able to scaffold one another and themselves by accessing their L1 reading comprehension strategies.

The overall findings indicated that, although the use of first language has been criticized in the existing literature, it has been supported by ESL teachers. In classrooms where both students and teachers share the same L1, there is a great tendency for using it while 
explaining meaning and difficult vocabulary, guiding interpretation, conveying lesson content, illustrating grammatical rules, organizing ESL classrooms and praising and encouraging learners. As a result, L1 has been shown to be helpful in increasing the interactions of ESL classrooms and improving ESL learning process.

Plentiful research into the nature of reading process have been conducted and various reading strategies and models and approaches have been proposed by Goodman1970; Ruddell, 1998; Krashen, 1993; Clarke and Silberstein 1977 (as cited in Brown, 2001). According to Goodman, reading in a second language is a more complicated and laborious task, requiring the learners decoding process, recognizing a multiplicity of linguistic signals and using their linguistic data processing mechanisms to impose some sort of order on these signals. According to Cook, 1992 and Upton, 1997 since L2 readers already have access to their first language, L2 reading is not a monolingual event by nature (as cited in Seng \& Hashim, 2006). As a result it can be quite legitimate to make benefit of L1 strategically as a short cut device in comprehending L2 texts.

Many studies have been carried out considering the use of L1 by L2 readers (Block, 1986; Claire, 1997; Kern, 1994; Upton, 1997) or investigating the role of L1 use in comprehending L2 texts (Cohen, 1996; Garcia, 2000; Seng \& Hashim, 2006). Some other research studied the language of thought of L2 readers implementing think-aloud protocol while comprehending L2 texts (Seng \& Hashim, 2006; Clair, 1997; Kern, 1994). They found that L2 learners use mental translation as a cognitive strategy in L2 reading comprehension process. However there has been no empirical research on the part of teachers' code switching as a compensating strategy to facilitate this laborious task of decoding and comprehending for L2 learners particularly beginners and low level proficient learners whose only comprehension tool at disposal is L1.

\section{Method}

\subsection{Participants}

Two groups of undergraduate students of Kerman Azad university, who were in their second year of bachelor in English teaching were selected. They were female with the age range of 19-26. These 46 intermediate students (based on Oxford Quick placement test) divided randomly into two groups of 23 , they were supposed to take reading comprehension course 3 (having passed reading comprehension $1 \& 2$ in the first and second semester). Their reading proficiency level was based on their final exam scores of reading comprehension 2 including proficient L2 readers with scores above the mean and less proficient L2 readers with scores below the mean and were distributed in both groups randomly.

\subsection{Instruments}

To determine the participants reading comprehension proficiency level at the beginning of the course a reading comprehension pretest was administered adopted from IELTS preparation and practice reading and writing academic, containing 14 multiple choice items each. The texts were selected culturally neutral with a moderate level of difficulty (intermediate). Both groups received the same reading materials during the course. An equivalent posttest with the 
same level of difficulty from the same source was administered at the end of the study.

\subsection{Procedure}

At the beginning of the semester a pretest of reading comprehension was taken to see the level of reading proficiency of both groups. The students whose scores were within the domain of (2-10 out of 10) were selected with a distribution of high achievers and low achievers in both groups. During the course the teacher practiced reading skill with the students of both groups using the same texts, procedures, approaches (top-down, bottom-up) and strategies. When the students faced difficult semantic, syntactic and structural features in the texts, the teacher made clarification using L2 only in the control group and switching to L1 in the experimental group. It should be noted here that teacher's switching to L1 was not pure translation of the difficult sections, but examples, explanations, interpretation and pertinent anecdotes. At the end of the semester a post test of reading comprehension was taken. The recorded post test scores and pretest scores were used as the two measures of proficiency to compare the two groups.

\subsection{Data Collection and Data Analyses}

Descriptive analysis and inferential statistics were conducted on the data using the Statistical Package for Social Science (SPSS). Frequencies, mean and standard deviation were computed to study the participants' pretest and posttest scores and accordingly to determine their level of reading proficiency. T-test and paired T-test were performed to compare the results in both groups and to determine if there were significant differences before and after implementing the strategy.

\subsection{Research Hypotheses}

- First: there is no difference in the students' reading comprehension scores in both control and experimental group before the teacher's instruction.

- Second: there is no difference in the students' reading comprehension scores in both control and experimental group after the teacher's instruction and implementing code switching strategy

- Third: There is no difference in the students' reading comprehension scores in the control group before and after the teacher's instruction.

- Forth: There is no difference in the students' reading comprehension scores in the experimental group before and after the teacher's instruction.

\section{Results}

Table 1 gives the descriptive statistics for the distribution of the participants.

Table1. Frequency distribution in each group

\begin{tabular}{ccc}
\hline group & frequency & frequency percentage \\
\hline control & 23 & $50 \%$ \\
experimental & 23 & $50 \%$ \\
total & 46 & $100 \%$ \\
\hline
\end{tabular}




\section{Macrothink}

Table 2 gives the descriptive statistics for the pretest and posttest mean scores in control and experimental groups. It is evident that the mean scores for control group did not change significantly before and after instruction, however in the experimental group the mean scores change to a higher level from pretest to post test.

Table 2. Results of pretests and posttests

\begin{tabular}{cccc}
\hline \multirow{2}{*}{ Time } & \multicolumn{1}{c}{ Statistics } & Mean & Std. Deviation \\
& $(\mathrm{n} 1=23)$ control & 5.17 & 2.08 \\
\multirow{2}{*}{ Before instruction } & $(\mathrm{n} 2=23)$ experimental & 4.35 & 2.55 \\
\hline \multirow{2}{*}{ After instruction } & $(\mathrm{n} 1=23)$ control & 5.39 & 2.06 \\
& $(\mathrm{n} 2=23)$ experimental & 6.61 & 1.70 \\
\hline
\end{tabular}
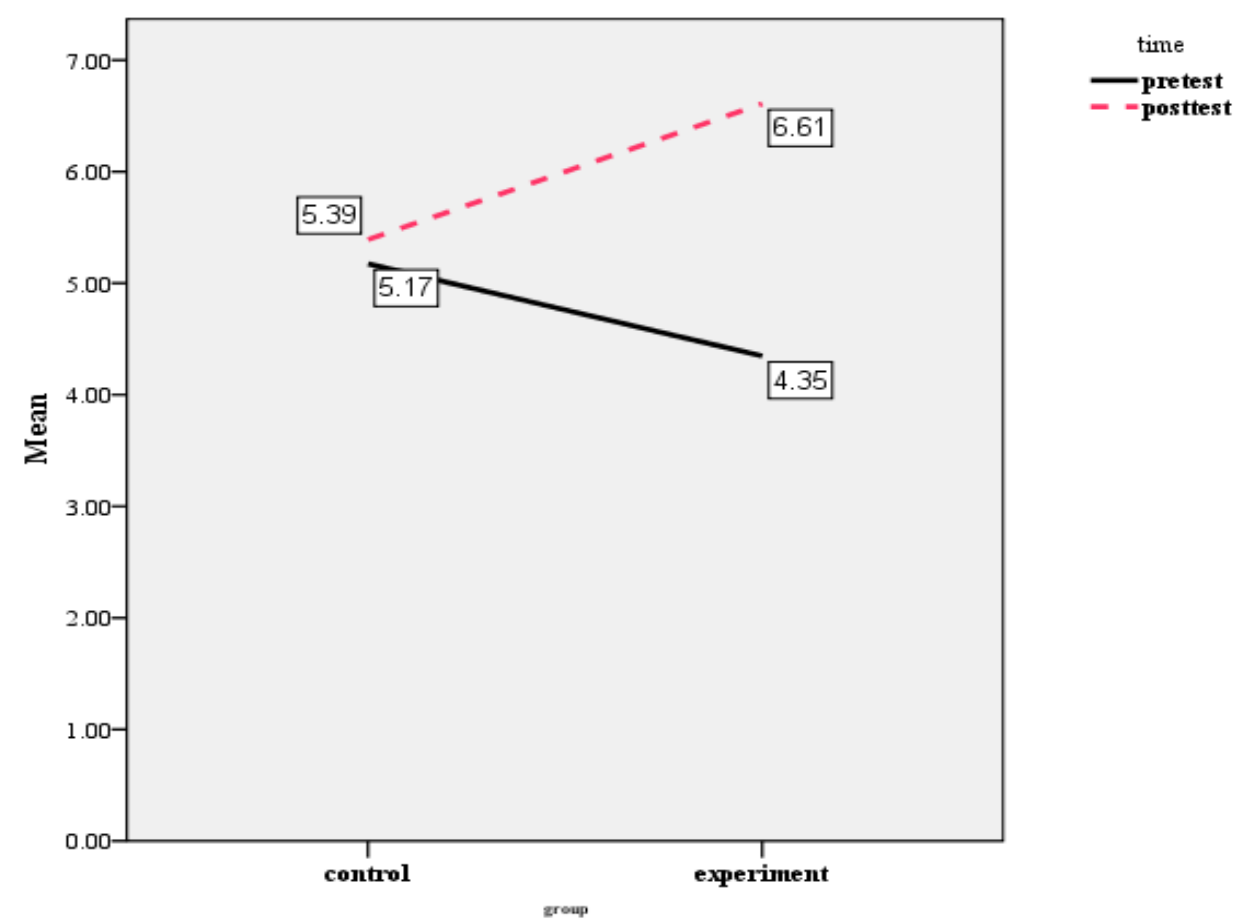

Figure 1. The linear graph of reading comprehension scores based on time and group

The groups' means across two testing times are presented graphically in figure 1 . It is evident that the experimental group underwent an improvement over the control group.

To investigate the first research Hypotheses T-test was used (Table 3). According to the significance level of $\geq .05$ with more than $95 \%$ confidence it can be said that there was no significant difference between the scores of the two groups before the instruction and teacher's implementing code switching strategy $(t=1.20, d f=44, p \geq .05)$. 
Table 3. T-test to compare the scores in the two groups before the Instruction

\begin{tabular}{ccccccc}
\hline group & $\mathrm{n}$ & Mean & sd.Deviation & T-Test & Sig & df \\
\hline control & 23 & 5.17 & 2.08 & & & \\
\cline { 1 - 3 } experimental & 23 & 4.35 & 2.55 & 1.20 & 0.2 & 44 \\
\hline
\end{tabular}

To investigate the second hypothesis, the independent T-test was used (table.4). According to significance level of $\leq .05$, with more than $95 \%$ confidence it can be said that the scores were significantly different in the two groups. $(t=-2.19, d f=44, p \leq .05)$ and comparing the mean of both groups indicated that the scores in the experimental group $(M=6.61, S D=1.70)$ were higher than the scores in the control group $(M=5.39, S D=2.06)$ that is to say that after teacher's instruction and implementing code switching the scores in the experimental group increased.

Table4. T-test to compare the scores in both groups after the implementation of code switching strategy

\begin{tabular}{ccccccc}
\hline Group & $\mathrm{n}$ & Mean & Std.Deviation & T-Test & Df & Sig \\
\hline Control & 23 & 5.39 & 2.06 & & 44 & \\
\cline { 1 - 5 } Experimental & 23 & 6.61 & 1.70 & & & \\
\hline
\end{tabular}

To investigate the third question T-test was used Table 5. According to the significance level of $\geq .05$ with more than $95 \%$ sure it can be said that the scores in the control group were not significantly different before and after the instruction. $(t=0.61, d f=22, p \geq .05)$.

Table 5. Paired T-test to compare the scores in the control group before and after the Instruction

\begin{tabular}{|c|c|c|c|c|c|c|}
\hline Time & $\mathrm{N}$ & Mean & Std.Deviation & T-Test & df & Sig \\
\hline Pretest & 23 & 5.17 & 2.08 & \multirow{2}{*}{0.61} & \multirow{2}{*}{22} & \multirow{2}{*}{0.5} \\
\hline Posttest & 23 & 5.39 & 2.06 & & & \\
\hline
\end{tabular}

To investigate the last question of the study paired T test was used (table.6). According to the significance level of $\leq .01$ with more than $99 \%$ confidence it can be stated that the scores in the experimental group were significantly different before and after the instruction $(t=-5.47$, $d f=22, p \leq .01$ ). That is to say; after teacher's implementing code switching (posttest) the mean of the scores in the experimental group $(M=6.61, S D=1.70)$ was higher than the mean before not utilizing code switching (pretest). $(M=4.53, S D=2.55)$

Table 6. Paired T-test to compare the scores in the experimental group before and after the instruction

\begin{tabular}{ccccccc}
\hline Time & $\mathrm{n}$ & Mean & Std.Deviation & T-Test & df & Sig \\
\cline { 1 - 1 } Pretest & 23 & 4.35 & 2.55 & -5.47 & 22 & 0.0001 \\
\cline { 1 - 4 } Posttest & 23 & 6.61 & 1.70 & & & \\
\hline
\end{tabular}




\section{Macrothink}

As Table 7 displays the participants raw scores in experimental group overall increased from pretest to posttest however high scores in this group didn't change which indicates no improvement with participants with high level of reading proficiency.

Table 7. The relation of individual pretest and posttest scores in both groups

\begin{tabular}{|c|c|c|c|}
\hline \multicolumn{2}{|l|}{ Control } & \multicolumn{2}{|c|}{ Experimental } \\
\hline Pretest & Posttest & Pretest & Posttest \\
\hline 3 & 4 & 7 & 7 \\
\hline 4 & 5 & 8 & 8 \\
\hline 7 & 7 & 8 & 8 \\
\hline 8 & 9 & 3 & 6 \\
\hline 7 & 5 & 2 & 3 \\
\hline 5 & 6 & 7 & 9 \\
\hline 6 & 6 & 8 & 8 \\
\hline 9 & 8 & 3 & 8 \\
\hline 4 & 5 & 9 & 9 \\
\hline 2 & 3 & 2 & 7 \\
\hline 3 & 4 & 6 & 6 \\
\hline 6 & 2 & 7 & 8 \\
\hline 3 & 3 & 4 & 6 \\
\hline 2 & 3 & 3 & 6 \\
\hline 4 & 5 & 2 & 7 \\
\hline 1 & 3 & 1 & 5 \\
\hline 6 & 5 & 1 & 3 \\
\hline 5 & 6 & 1 & 6 \\
\hline 7 & 3 & 8 & 9 \\
\hline 4 & 4 & 4 & 5 \\
\hline 8 & 9 & 4 & 7 \\
\hline 5 & 5 & 2 & 7 \\
\hline 3 & 2 & 3 & 7 \\
\hline
\end{tabular}

\section{Discussion and Conclusion}

This study set out to examine the effect of teachers' codeswitching to 11 on learners' second language reading comprehension skill. The findings in relation to the research questions and hypotheses are as follows:

Research question 1: how can codeswitching be utilized as a strategy by 12 teachers? It can be concluded that since any procedures that serves as a way of reaching a goal is considered as a strategy and here the results of the study showed the teacher's goal (improving reading comprehension proficiency) is fulfilled, then code switching can be utilized and regarded as a teaching strategy.

The results of this study suggest that if only L1 is utilized by the teacher as a strategy to the extent of clarification on complex syntactic or semantic structures, the learners will feel free from getting confused or bewilderment in comprehending L2 texts. As indicated in the study they achieved higher scores (table7). Therefore, they won't lose their confidence and 
incentive to produce L2 output something which is normally avoided in case of getting frustrated. Just as found by (Van Lier, 1995) the use of L1 can make L2 input more salient for the learner, hence enhancing intake. It is also in line with the claim made by (Swain, 1995 \& Long, 1996) that L2 learners need L1 to negotiate the meaning of the input to produce output.

It has been proved through other researches that L1 is ever present in the minds of L2 learners (Cook, 1992) and translation is a frequent cognitive strategy in the process of L2 reading comprehension task (Anderson, 1991; Block, 1986; O’Malley and Chammot, 1990; Kern, 1994; Upton, 1997). Macaro (2001) also made an interesting and justified example in his findings, asserting that most learners find bilingual dictionaries a useful tool in carrying out reading and writing tasks. Taking away the bilingual teacher's right to code switch is like taking away the student's right to use a bilingual dictionary within which the reading comprehension task is a way of lightening the cognitive load. Then the question is, why shouldn't L2 teachers make benefit of this asset particularly when they share the same L1 with the learners.

As the results of this study showed, the learners made progress in terms of output, the group under the experiment outperformed in their reading proficiency test after they received code switching strategy from their teacher (table7). Hence the concern for lack of input and accordingly no successful output will be less prominent here. It also supports the interactionist learning theory (Ellis, 1994) which suggests that input alone is not enough for language acquisition to take place.

Regarding this fact the second question of the research, whether this strategy has any impact on L2 learners reading comprehension proficiency, is automatically answered (table. 7). Having noticed the scores (high \& low out of 10) before and after the instruction in both groups, it can be concluded that learners with low level of reading proficiency made benefit of teachers' implementing strategy while high scores in both groups haven't changed significantly, it seems that learners with higher reading proficiency didn't make benefit of the strategy.

The answer to the last question of the research; whether learners with different level of reading proficiency make equal benefit of teacher's code switching strategy; is that, since learners' high scores or so to say their reading proficiency haven't changed before and after the instruction then code switching or teacher's use of L1 hasn't had any effect on them , in other words, although learners with higher reading proficiency didn't make benefit of teacher's shifting to L1 strategy as well as learners with low reading proficiency, they didn't have a setback either (table 7). This part of the study also reassures Macaro's findings (2001) that teachers use more L1 with 'less able' learners because these learners find it more difficult to infer meaning and therefore easily get more frustrated.

The implication that could be emerged from this study is that code switching can be introduced into the language teaching process as a compensating teaching strategy through which learners can benefit at early stages of learning a second language. This study investigated reading comprehension skill, further research can be conducted to examine other aspect of 12 language skills regarding L1. Here second language teachers can make benefit of 
11 to provide learners with clarification and interpretation in order to facilitate comprehension. This strategy helps to lower the affective filter and boosts the learners' confidence and consequently their competence regardless of excessive down grading use of L1 as a source of negative transfer. This study is constrained by codeswitching as a teaching strategy, it can be further completed and more comprehensive by taking the learning strategies into account as well.

\section{References}

Anderson, N. J. (1991). Individual differences in strategy use in second language reading and $\begin{array}{llll}\text { testing. } \quad \text { Modern } \quad \text { Language } & \text { 450urnal, }\end{array}$ https://doi.org/10.1111/j.1540-4781.1991.tb05384.x

Asher, J. (1993). Learning another language through actions:The complete teacher's guidebook (4th ed.). Los Gatos, CA: Sky Oaks Productions.

Atkinson, D. (1987). The mother tongue in the classroom: a neglected resource? ELT Journal, 41(4), 241-247. https://doi.org/10.1093/elt/41.4.241

Brown, H. Douglas. (2001). Teaching by Principles (2nd Ed.). White Plains, NY: Pearson Education.

Block, E. (1986). The comprehension strategies of second language readers. TESOL Quarterly, 20, 463-494. https://doi.org/10.2307/3586295

Cohen, A. D. (1996). Verbal reports as a source of insights into second language learner strategies. Applied Language learning, 7(1\&2), 5-24.

Cook, V. J. (1992). Evidence for multicompetence. Language learning, 42, 557-591. https://doi.org/10.1111/j.1467-1770.1992.tb01044.x

Dilin, L. (2004). South Korean high school English teachers' code switching: questions and challenges in the drive for maximal use of English in teaching. TESOL QUARTERLY Journal, $38(4)$.

Dodson, C. J. (1967). Language teaching and the bilingual method. London: Sir Isaac Pitman \& Sons Ltd. 13.

Ellis, R. (1994). The Study of Second Language Acquisition. Oxford: Oxford University Press.

Fatemi et al. (2014). The Effect of code-switching strategies on listening comprehension of EFL Students. International Journal of Language Learning and Applied Linguistics World, 7(1), 71-78.

Garcia, G. E. (2000). Bilingual children's reading. In M.Kamil, P. Mosental, D. Pearson, \& R. Barr (Eds), Handbook of reading research, 3, 163-179.

Harmer, J. (2001). The Practice of English Language Teaching (3rd Ed.). Longman.

Kern, R. G. (1994). The role of mental translation in second language reading. Studies in Second Language Acquisition, 16, 441-461. https://doi.org/10.1017/S0272263100013450 


\section{Macrothink}

International Journal of Social Science Research

ISSN 2327-5510

2018, Vol. 6, No. 1

Long, M. H. (1996). Input, interaction and second language acquisition. In H. Winitz (Ed.), Native language and foreign language acquisition. Annals of the New York Academy of Sciences, 379, 259-278.

Macaro, E. (2001 b). Analyzing student teaches' codeswitchingin foreign language classrooms: Theories and decision making. Modern Language Journal, 85(4), 531-548. https://doi.org/10.1111/0026-7902.00124

Nunan, D., \& Lamb, C. (1996). The self-directed teacher: Managing the learning process. Cambridge Uninversity Press.

O'Malley, J. M., \& Chammot, A. U. (1990). Learning strategies in second language acquisition. Cambridge: Cambridge University Press. https://doi.org/10.1017/CBO9781139524490

Sahanaya, W. et al. (2003). IELTS Preparation and Practice. Oxford University Press.

Seng, G. H., \& Hashim, F. (2006). Use of L1 in L2 reading comprehension among tertiary ESL learners. Reading in a Foreign Language, 18(1), April 2006.

Swain, M. (1995). Three functions of output in second language learning. In G. Cook \& B. Seidlhofer (eds), Principles and practice in the study of language. Oxford: Oxford University Press.

Swain, M., \& Lapkin, S. (2000). Task-based second language learning: The uses of the first language. Language Teaching Research, 4, 251-274. https://doi.org/10.1177/136216880000400304

Teik \& Lian, (2013). A preliminary study of teacher code switching in Islamic education instructions. The English Teacher, XLII(1), 1-24.

Turnbaull, B., \& Sweetnam Evans, M. (2017). The effects of L1 and L2 group discussions on L2 reading comprehension. Reading in a Foreign Language, 29(1), April 2017.

Upton, T. A. (1997). First and second language use in reading comprehension strategies of Japanese ESL students. TESL-EJ, 3(1).

Van Lier, L. (1995). Introducing language awareness. London: Penguin English. 14.

Wang, J. (2005). Mother tongue in the English language classroom: A case of one school. ASL TEFL Journal, 2(4), 17-39.

\section{Copyright Disclaimer}

Copyright for this article is retained by the author(s), with first publication rights granted to the journal.

This is an open-access article distributed under the terms and conditions of the Creative Commons Attribution license (http://creativecommons.org/licenses/by/3.0/). 